\title{
State-Producer Group Relations and Economic Policy Formation in Postindustrial Society
}

\author{
Mark James Gobeyn, Bradley University
}

\begin{abstract}
This paper examines recent attempts to link the emergence of postindustrial/postmaterialist public value structures to the recent decline of corporatist policymaking and interest intermediation practices in western Europe. It is argued that the decline of corporatist forms in Europe can be linked more persuasively to the economic transformation commonly ascribed to the postindustrial phenomenon, than to the "societal value changes" that accompanied that transformation. It is argued here that, in forcing greater discipline upon labor, the structural economic features of postindustrial society have pre-empted the functional role of postwar corporatist political structures. Consequently, capitalists appear no longer willing to maintain centralized concertative linkages with trade unions within state policymaking stuctures.
\end{abstract}

Recent literature on the subject of corporatism reveals scholarly awareness that certain changes have transpired within the interest intermediation and public policymaking systems of some of Europe's advanced capitalist democracies (Regini 1986; Schmitter 1989; Streeck and Schmitter 1991). This literature suggests that within those countries where corporatistic political bargaining practices seemingly had become entrenched during the 1950s and 1960 s, declines in either the effectiveness and/or utilization of corporatist political institutions, or in the concertability of producer groups and the state (at the federal level), seem to be evident.

In searching for an explanation for this apparent pattern of corporatist decline and instability, certain analysts have turned to literature associated with the subject of postindustrialism, in particular, that which is related to the emergence of so-called "postmaterialist" public value structures. In brief, they argue that traditional corporatist modes of interest intermediation and public policymaking, which were said to be elitist, exclusive, and narrowly focused (in terms of policy scope and policy objectives), came to be viewed by societal members holding postmaterialist "value orientations" as unrepresentative and largely nonresponsive to their specific policy agendas (Harrison 1980; Beer 1982; Kitschelt 1986, 1990; Offe 1987; Kuechler and Dalton 1990; Hatch 1991; Streeck and Schmitter 1991). Essentially, corporatism, as a form of political system in which "privileged" societal producer groups were integrated formally into the state's policymaking apparatuses, was seen

MARK GOBEYN is Assistant Professor of Political Science at Bradley University, Peoria, IL.

The American Review of Politics, Vol. 14, Autumn, 1993: 395-415

(C)1993 The American Review of Politics 
as encouraging a prioritization of economic policy objectives - growth, employment stability, etc.- - over the types of "quality of life" concerns advanced by individuals and interest groups of the postmaterialist persuasion. As such, it is argued that, due to its insufficient representation of the postmaterialist agenda, the corporatist style of governance during the 1980s became subject to political reform movements originated by postmaterialistoriented interest groups and parties, which subsequently contributed to partial or complete governmental dismantling of existing corporatist institutional arrangements throughout much of western Europe.

Building upon recent literature that attributes the decline of corporatism to certain domestic and international economic factors (Streeck 1984; Lehmbruch 1985; Wilson 1985; Schmitter 1989; Streeck and Schmitter 1991), this paper challenges attempts to link the emergence of postindustrial/postmaterialist public value structures to the ongoing decline of significance of national-level corporatist policymaking institutions in advanced capitalism. It is argued here that the decline of corporatist governance in the European democracies can be linked more persuasively to the various economic and technological changes commonly ascribed to the postindustrial transformation. Such changes have acted to weaken the power position of labor vis-àvis capital enough to facilitate increased business opposition to maintaining centralized concertative linkages with trade union representatives within state policymaking apparati. The decline of corporatism, therefore, should be attributed more to destabilizing tendencies that have appeared within corporatist political structures than to forces (such as public value changes) that have emerged in the external socio-political environment.

\section{Corporatism and the Postindustrial Transformation}

Much has been written on the political, economic, and social implications of postindustrialism (Lasch 1972; Bell 1973; Huntington 1974; Heisler 1974). And while authors have identified a number of important aspects and consequences of the postindustrial phenomenon, two features of postindustrial society seem to have received the greatest attention. The first relates to the economic and occupational changes commonly associated with postindustrialism. As Tsurutani notes:

The major features of postindustrial society that emerge include, among others, the majority of labor employment to be found in the service sector, the service sector generating a larger share of the gross national product (GNP) than the agricultural and manufacturing sectors combined, a high level of affluence and mass material wellbeing, the national economy becoming "knowledge-intensive" (1977, 6-7). 
This knowledge intensiveness is of course the product of the postindustrial economy's reliance upon modern technology, which reduces the demand for labor in the traditional agricultural and manufacturing sectors and increases the demand for, and opportunities, in the service sector (Pierce et al. 1989, $3)$.

In addition to and in consequence of these various economic features, postindustrial society is also characterized by the presence of a distinct public value structure, one which is said to differ substantially from that predominant in the western democracies during preindustrial and industrial times. The most widely accepted interpretation of the "value change" associated with postindustrial society is that of Inglehart (1971, 1977, 1981). Following Abraham Maslow's assumption that individual value priorities are determined largely by given socioeconomic circumstances, Inglehart contends that in postindustrial societies, where widespread affluence and economic prosperity are prevalent, growing numbers of citizens have come to embrace value structures that reflect "higher order," postmaterialist needs.

The implications of the emergence of postmaterialist value orientations among large segments of western publics are said to be numerous, but two value-induced political changes seem most critical. The first relates to the political issue agenda, which is said to have been altered in the western democracies as a result of the rise of postindustrialism. As holders of higher level needs, postmaterialists advocate a political agenda that includes such "quality of life" items as environmental protection and regulation, social and political equality, and nuclear disarmament. These "new issues" quite obviously differ from those economic and security issues that traditionally have received the bulk of governmental attention.

A second important political development relates to the practice of policy formation. For Inglehart, postmaterialists show a distinct preference for participatory democracy and greater citizen involvement in state policymaking processes $(1979,314)$. And as the political influence of individuals embracing postmaterialism has expanded (primarily through the formation of reform-minded interest groups) over the past decade or so, governments in the western democracies are said to have been pressured into democratizing their once exclusive, elite-directed decision making processes.

Given these observations and theoretical assumptions, it is not surprising that analysts would seek to link the decline of corporatist governance in western Europe to the rise of postmaterialist value structures. As a system of policymaking that is said to be both materialist-oriented and exclusive of mass participation, corporatism clearly conflicts with the value priorities of the postmaterialist generation. Thus, while corporatism emerges from a 
desire for socioeconomic and political system stability, in practice it nonetheless forces anti-system orientations upon "outside" groups, for whom disrupting the system appears the only path to influence (Wilson 1990, 72).

This interpretive approach to the rise of postmaterialist-oriented social movements and their supposed impact on corporatism suggests, in a nutshell, that the corporatist style of governance was inherently incapable of addressing the panoply of issues associated with the postmaterialist agenda. Consequently, as the political influence of postmaterialist interest groups and parties became more pronounced in the European democracies, the viability and legitimacy of corporatism as a guiding system of interest group/government interaction inevitably diminished-hence its demise and subsequent displacement by more pluralistic methods of interest articulation and policymaking (see Hatch 1991).

While much of this argument may appear to make sense, at least from a theoretical point of view, it remains, as Wilson $(1990,72)$ notes, largely unsubstantiated. That is, little empirical evidence has been presented to illustrate either a clear relationship between the rise of postmaterialist pressure groups and the presence of corporatist modes of interest intermediation, or that such groups actually have had enough political influence to force substantive change upon state policymaking practices and institutions. Indeed, on the contrary, Wilson's own analysis reveals that existing evidence does not support the notion that the emergence and relative strength of postmaterialist interest organizations are systematically related to the prevailing mode of interest intermediation, or that these groups' activities have had the effect of systematically reducing the efficacy of corporatist policymaking institutions (Wilson 1990, 72-78; Kaase 1990, 99). ${ }^{1}$

Wilson's findings, while perhaps not definitive, do suggest that it may be useful to look beyond the postmaterialist value change literature to the possibility that the collapse of corporatist arrangements may be attributable to developments unrelated to changes in societal value structures. Such an exploration is undertaken below, where it is argued that the emergence of instability within and subsequent decline of corporatist forms in Europe can be linked most convincingly to interest associations of capital, which during the early 1980s arguably assumed a distinct anticorporatist bias. This interpretation, while calling into question the postmaterialist societal value structures, does not abandon the notion that the postindustrial transformation has disrupted corporatist forms of governance. Indeed, as shall be seen, certain characteristics and consequences of the postindustrial phenomenon clearly are related to the collapse of corporatist concertation in advanced capitalism. 


\section{Corporatist Decline in Postindustrial Society}

Thus far, literature linking the decline of corporatism to changing economic conditions has focused generally upon two economic developments alleged to have affected the conditions necessary for manufacturing industries to remain globally competitive. The first relates to changes in technology that have allowed for greater product range flexibility and specialization. For Streeck (1984), Wilson (1985, 111), and Streeck and Schmitter (1991, 146-147), increased competition in the global economy forced many industries to abandon mass production practices in favor of more specialized goods production. Corporatism, which tended to generate "constraining" and "inflexible" rules and regulations, inhibited this necessary shift in production and thus needed to be abandoned in favor of more decentralized, sectoral bargaining arrangements. The second change, as Lange and Wallerstein $(1992,2)$ note, is the increased openness of the international economy, particularly the integration of capital and labor markets associated with the creation of a single European market. This trend is said to have reduced significantly the need for corporatist negotiations at the level of the nation state. Both changes are said to have altered capital's view toward corporatist governance while simultaneously weakening the power position of organized labor. The result is held to be that capitalists have wanted to dismantle corporatist wage setting and industrial policymaking practices (Lange and Wallerstein 1992, 2).

These analyses of the causes of the collapse of corporatism offer some fairly convincing evidence that economic circumstances indeed have facilitated that collapse. More importantly, they reinforce the argument below that capitalists should be seen as the primary instigators of corporatism's decline. Thus, they appear to provide a reasonably sound theoretical basis upon which a more comprehensive capitalist-centered explanation for the decay of corporatist practices and institutions can be constructed.

To understand more fully why capital should be seen as the primary instigator of the ongoing corporatist decline and instability in the western European democracies, it is necessary first to examine the circumstances that contributed to the eventual development of corporatist governance within these societies. In so doing, it is instructive to follow the heretofore littlediscussed theoretical model of Leo Panitch (1977, 1980, 1981, 1986), whose interpretation of corporatism draws upon the more general structuralistMarxist analysis of the capitalist state.

In his various writings on corporatism, Panitch appears to agree with the more widely cited liberal corporatist theorists (e.g., Schmitter 1974; 
Wilson 1990) that corporatism performs an integrative function. By incorporating society's producer groups into its policymaking structure, and by granting them official policymaking and administrative roles, the corporatist state is said to promote greater cooperation and consensus between two otherwise combative social groups (capital and labor). However, instead of assigning corporatism the status of a "new political system," as liberal theorists appear to have done, Panitch views corporatism in much more limited terms, arguing that it is only with the activities of producer groups that corporatist institutional arrangements are concerned. Other interest groups are not affected directly by corporatism. These groups continue for the most part to function within more traditional pluralistic bargaining environments. Thus, Panitch sees corporatism as a limited political structure that integrates socioeconomic producer groups "through a system of representation and cooperative mutual interaction at the leadership level and mobilization and social control at the mass level" $(1980,173)$.

For Panitch, the integration of trade unions into corporatist political structures has its roots in concerted, direct state efforts to contain the bargaining powers of organized labor and to secure general working class docility and wage demand moderation. By generating near-full employment, the rapid economic growth experienced by the liberal democracies following World War II helped to strengthen the political and economic bargaining powers of the working class. With relatively small reserve armies of labor in place to act as restraints upon wage demands, labor was able to demand and receive unprecedented increases in wages and fringe benefits during the immediate postwar period. The timing and institutionalization of corporatist political structures, Panitch contends, appears to be linked to this rise of working class power. The state, recognizing the potential for increased labor militancy and social instability, moved to integrate trade unions into corporatist political structures $(1980,174)$. This integration process, while facilitating the realization of an objective labor long had sought after, viz., the state's grant of official policymaking status, was accompanied by the imposition of certain key conditions. Of particular importance was the requirement that trade union elites work in concert with capital to promote continued economic growth and stability. Of course, a central component of this strategy was that union leadership impose wage demand moderation upon the rank-and-file. In effect, a trade-off was struck by the state's creation of corporatist political structures. By granting labor a voice in its policymaking apparatus, the state was able to achieve for capital what the market alone no longer could attain - working class wage restraint and labor discipline. 
Elsewhere (Gobeyn 1993, ch. 3) I attempt empirical validation of Panitch's theory through comparative historical analysis of the emergence of corporatist governance in those societies-Austria, the Netherlands, Sweden, and Norway - most commonly classified as having the most extensive corporatist institutional arrangements. In brief, the analysis suggests that in each of these societies the creation of corporatist political structures and the actual, formal institutionalization of corporatist governance occurred during the expansionary years of the 1950 s, when economic growth was sufficient to generate near-full employment. These labor market conditions quite obviously had the effect of improving the power position of the working class vis-à-vis capital and the state. Also contributing to the growth of labor's bargaining powers during this period were movements toward trade union organizational centralization. In postwar Austria, for instance, the major trade union federation (OGB) was able to consolidate and centralize the once ideologically and organizationally fragmented Austrian trade union movement to the point where, by the early 1950 s, it stood as the sole representational arm for nearly all of the country's workers. In Norway and Sweden, as well, dominant labor federations were quick to establish extremely high levels of control and authority over their member unions. Finally, in the Netherlands workers came to be affiliated with one of three major trade union federations within a few years of the war. And while each remained organizationally independent of the others, by the early $1950 \mathrm{~s}$ these three labor organizations had become unified on most major social and economic policy issues. More importantly, they had assumed a general posture of working together in negotiations with employers' associations.

Favorable employment conditions combined with patterns of increasing trade union organizational strength and solidarity, then, gave labor in each of these countries unprecedented amounts of political and economic bargaining power. Arguably, it was in response to these labor market conditions, which in the absence of effective institutions of class mediation should contribute to increased labor militancy (Cameron 1984), that governments began to promote and institutionalize corporatist modes of industrial relations and economic policymaking. In effect, the state's institutionalization of concertative linkages within its policymaking and administrative apparati in each of the above cases appears to have resulted from the realization that the achievement of trade union wage restraint and rank-and-file discipline no longer could be left to market forces alone. Instead, such labor force conditions could be realized more easily through a state-interventionist strategy based on integrating working class representatives into the state's growth-driven economic policymaking structure. Consistent labor cooperation with capital and the state (in regard to incomes and industrial policies) 
then would be attained through trade union participation in an institutionalized form of concertative management.

Setting aside the much-debated question of whether or not labor actually has benefited from corporatism, there seems to be little doubt that the institutionalization of corporatist forms represented an advantageous situation for industry. After all, "trade union wage restraint is something that capitalists always have use for" (Streeck 1984, 273), and while the integration of labor into the state's policy apparatus perhaps reduced the economic decision making authority and flexibility of capital in those societies where corporatism developed, it at least assured the continued presence of working class wage demand moderation and labor discipline, two conditions that are essential for the consistent accumulation of capital and for the maintenance of a stable, bourgeois-dominant regime.

But if, indeed, the creation of corporatist forms has been notably beneficial for industry, then it would seem that, contrary to our hypothesis, organized capital is not likely to be a primary instigator of conflict and instability within corporatist political structures. Yet, if one accepts the above-developed argument (that the institutionalization of corporatist governance within the liberal democracies began during periods when economic conditions enhanced the bargaining powers of organized labor, and that corporatistic integration of trade unions into state policymaking apparati took place in order to preserve or secure wage restraint and labor discipline), then it becomes possible to envision a scenario wherein if the bargaining strength (and hence the potential militancy) of labor were to recede, the perceived necessity of corporatism also might diminish in the eyes of organized capital and the capitalist state. Capitalist opposition to the maintenance of corporatist structures would seem likely to emerge if changes in the economy were to facilitate a restoration of the market's ability to secure trade union wage restraint and general labor docility. With the bargaining power and disruption capability of the industrial workforce effectively reduced by market conditions, corporatist governance would lose much of its utility, as it no longer would be viewed by organized business as a prerequisite of profitability. Instead, the benefits to industry of corporatist arrangements now would be perceived to be attainable through less inclusive forms of economic policymaking and more decentralized, market-determined approaches to labor-management relations. Capital no longer would need to grant organized labor an official policymaking and administrative role, for its substantive input on matters of economic and social policy no longer would be crucial to the maintenance of low levels of labor militancy and, hence, social and economic stability. And, de-emphasis of corporatist concertation would permit capitalists greater control and flexibility in 
making investment decisions. Essentially, a freer, more open investment climate would prevail if labor's power to influence economic policy was circumvented through the dismantling of corporatist policymaking bodies or, if more practical, through the increased unwillingness of employers' associations to cooperate on these bodies or to comply with agreements reached within them.

In thinking about the types of market conditions and general economic circumstances that might weaken the bargaining strength of organized labor to the point where capitalists might begin to think of dismissing corporatism, one inclines to turn initially to the unemployment-inducing recessions that frequently have plagued the economies of the western European democracies since the early 1970s. But while the periodic downturns of the past two decades have generated unemployment rates significant enough at times to reduce the bargaining power of organized labor (particularly in Germany, Holland, and Belgium), the recessions themselves probably should not be seen as creating the kind of irreversible reductions in trade union bargaining strength that would contribute to the formation and entrenchment of anticorporatist attitudes on the part of capital. Other tendencies within the modern advanced capitalist economy must be identified if one is to develop a satisfactory capitalist-centered theory of corporatist decline. Thus, a discussion of some of the characteristics and consequences of postindustrialism is in order here.

As noted earlier, postindustrial society is characterized by its servicedominant and technology-intensive economy. The emergence of these two tendencies was facilitated in large part by certain transformations in the international capitalist system. One was the much-discussed development during the 1970s of the economies of a number of heretofore "third world" societies, particularly in the "newly industrializing countries" (NICs) of East Asia. As these nations' economies expanded, so did their ability to assume a greater responsibility for producing manufactured goods for the world economy. A new international division of labor thus was created, as manufacturing industries in the higher-wage western democracies increasingly became unable to compete in the world market with their lower-wage counterparts in the developing regions. As a result, the advanced industrial economies underwent patterns of disinvestment in many goods-producing sectors, accompanied by expansions of investment in the service-related industries. This movement toward service-oriented industrial restructuring, coupled with capital's increased willingness to install labor-saving technologies into the production processes of remaining manufacturing operations (to become more competitive globally) had the effect of reducing the availability of jobs in the manufacturing occupations in most of the western 
democracies, including those that have utilized corporatist forms of governance. During the period 1969-1987, for instance, the total number of workers employed in manufacturing sectors declined by 66 percent in Sweden, 41 percent in Belgium, 36 percent in Norway, and 24 percent in Germany. As might be expected, these reductions produced inevitable expansions of unemployment among large numbers of unskilled and semiskilled manufacturing workers (ILO 1975, 1986, 1990).

While this sequence of events has been well documented, and does not need to be described in any greater detail here, it is important to stress that the unemployment caused by the competition from the NICs and by the spread of labor-saving technologies is unique in that it is largely structural rather than cyclical. And while some economists pointed early on to the growing service-producing and "high-technology" sectors as the eventual providers of replacement jobs for dislocated unskilled and semi-skilled manufacturing workers, evidence today suggests that the new postindustrial economic order does not possess the job generation capacity to overcome its self-induced structural unemployment problems (Edwards 1986, 4).

The problems posed to organized labor by these seemingly permanent postindustrial labor market and occupational conditions thus far have proven to be largely insurmountable, and have forced the trade unions into a generally defensive position vis-à-vis capital. In effect, labor's ability to effect its will via collective bargaining (i.e., its position in the economic market) has been damaged by the fact that, due to the current size of the industrial reserve army, industrial action has become increasingly risky and ineffectual (Jacobi 1986, 43). Furthermore, attempts by the trade unions to regain their political and economic influence by organizing workers employed in the growing service sectors have met with little success, a circumstance that is probably attributable to the inherent unorganizability of many service industries, which have high turnover rates and tend to employ younger people who perceive their job status to be temporary (Wood 1991, 170).

Additional, perhaps even more damaging characteristics of postindustrial society have contributed to current patterns of trade union decline. As indicated, in postindustrial society the utilization of advanced technology and the continued development of new technologies have emerged as critical elements in the capital accumulation process. As such, the economies of the western democracies have become increasingly knowledge-intensive, as reflected not only in the aforementioned growth of labor-saving technologies for factory production processes, but in significant technological improvements in other economically vital areas, as well. Of particular significance here are the various technological breakthroughs in the transportation and communications industries. Over the past two decades technological 
advancements in these two areas have made it possible for capital to become extremely mobile. As Bluestone and Harrison $(1982,18)$ have noted, during the 1970s improvements in transportation and communications technologies made it possible for industrialists in the advanced capitalist societies to shift their production operations to foreign locations. Satellite-linked, computerbased communications systems, together with wide-bodied cargo jets capable of transporting physical commodities from one location to another in a matter of hours, gave capital an unprecedented amount of freedom to disinvest in and to relocate industrial plants. As with the occupational transformations outlined above, this "hypermobilization" of capital should be viewed as contributing to the ongoing decline in the bargaining strength of organized labor. With capital as mobile as it now is, industrialists have at their disposal an increased assortment of investment opportunities, including the possibility of moving manufacturing operations away from "expensive" domestic labor markets and into cheaper third world production environments.

By effectively reducing the organizational strength and bargaining power of labor, the increase in the portability of capital and the shift to service- and technology-intensive industrial bases in the western economies created the type of socioeconomic climate that would encourage employers to reduce their commitment to corporatism. Essentially, by acting to discipline labor these postindustrial economic features have assumed the functional role of the postwar corporatist political structure. Corporatism's utility thus has diminished in postindustrial society. As a result, one should expect to find-within those countries where corporatist forms of policymaking and wage setting have been utilized-increasing capitalist opposition to continuation of formal corporatist linkages with labor at the federal level. This opposition, as stated above, would be fueled by capitalist desire to create a "freer," more flexible economic decision-making environment, in which capital would regain its traditional dominance of economic management.

In the following section, an analysis of events of the past decade in two countries is presented in an effort to validate these assumptions. As shall be seen, in both Sweden and Germany seemingly entrenched federally-based corporatist political systems effectively have been dismantled, largely as a consequence of the assumption of a distinct anticorporatist posture by organized business.

\section{Corporatist Decline in Sweden and Germany}

In Sweden, the origins of the decline of corporatist governance can be linked persuasively to developments that transpired in 1980. On 1 May 
1980, over 110,000 workers represented by the Swedish Confederation of Trade Unions (LO) went on strike in response to an earlier lockout of over 600,000 employees by companies affiliated with the increasingly militant Swedish Employers' Confederation (SAF). This massive work stoppage, which lasted for ten days, signalled a virtual end to Sweden's voluntaristic, highly centralized wage determination system, as sectoral wage bargaining soon became commonplace. ${ }^{2}$

These developments, and the role played by organized capital in facilitating them, are summarized by Svensson:

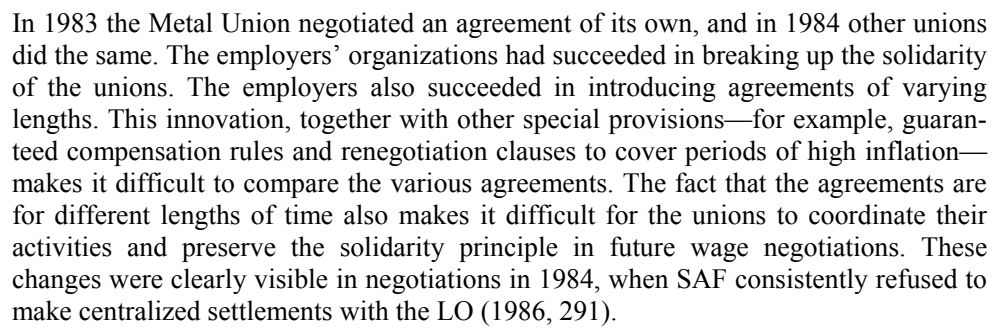

Though not linking these developments to a general theme of corporatist decline and instability in Sweden, Svensson's observations clearly serve the central point of this paper: actions taken by capitalists in response to labor's weakened economic bargaining position and inability to defend itself have been largely responsible for the decline of corporatist bargaining arrangements in western Europe.

With the case of Sweden, this assumption is substantially confirmed by the fact that, in addition to its concerted campaign to decentralize wage negotiation practices with labor, the SAF during the mid-1970s began to promote a number of fairly significant political and economic reformsmany designed to reduce the economic policymaking influence of the state and organized labor (and hence to reduce the influence of tripartite governmental institutions). These proposed reforms included privatization of certain public sector enterprises to provide new markets for capital; privatization of parts of the welfare system and expansion of the roles of private insurance and pension programs; reduction of income tax rates and of taxes on capital assets; restrictions on union activities and changes of labor laws; promotion of a more market-oriented economic policy with reduced state economic intervention; and segmentation and marginalization of the working class through job reclassifications and increasing wage differentials (Svensson 1986, 281-282). 
These proposals, reflected initially in the policy programs of Sweden's three major nonsocialist opposition parties during the 1970s, suggested a changed attitude on the part of capital toward Sweden's long-established system of corporatist concertation and Keynesian approach to economic management. Instead of adhering fully to principles of consensus and compromise, organized business in the mid-1970s became increasingly willing to shift toward more conflictual relations with trade unions and less willing to include labor in economic decision making processes. In effect, by pursuing the above objectives, and by becoming more militant in the process, capitalists appeared to mount a fairly concerted campaign to alter Sweden's existing corporatist-based structure for capital accumulation.

In light of the various nonsocialist party platforms of the 1970s, it is not surprising that organized capital found a fairly powerful ally in the bourgeois majority that governed Sweden between 1976 and 1982. Between 1980 and 1982, in particular, the government, in an attempt to revitalize the sluggish Swedish economy and to reduce inflation, shifted partially away from strict utilization of Keynesian interventionist techniques of economic management to policies that were more reflective of monetarist and supply-side principles (Korpi 1983, 227-229). In brief, these (often contradictory) economic doctrines promote the restriction of government expenditures and the circulation of money (to control inflation), as well as reductions in corporate and personal income tax rates (to stimulate savings and investment). Both schools argue that economic renewal and long-term prosperity require a "freeing-up" of market forces (Wanniski 1979).

Despite labor's open disapproval, the governing bourgeois coalition in 1980, 1981, and 1982 cut the federal budget by an annual average of 14.5 billion kronas. The government reduced sickness benefits, unemployment insurance payments, and benefits associated with the national health care system (OECD 1981, 1982). To stimulate increased private sector investment, a modest cut was made in Sweden's already low corporate tax rates (which in 1980 accounted for only 2.4 percent of total tax receipts, compared to an OECD average of 7.6 percent), and a tax incentive scheme designed to enhance the supply of risk capital was implemented (OECD 1982, 36).

Though relatively modest, these changes to Sweden's social security system and corporate income tax structure did represent a fairly "positive" state response to organized capital's campaign to reduce government intervention in the economy. More importantly, these new policies-implemented without the support or consent of the trade unions-left little doubt that the Swedish model of consultative, consensus-based policymaking had begun to erode. 
A further example of the erosion of the concertative principles associated with the Swedish system of corporatist governance is evident in the events that surrounded the controversial "wage earner fund" issue of the 1970s and 1980s. In the early 1970s, the trade unions began to promote a system of profit sharing in an effort to reduce the high profits that some companies enjoyed as a result of the unions' solidarity wage policy, which promoted the reduction of income differentials among workers across all industrial sectors. This scheme also was seen as a means of reducing the concentration of capital and of giving workers increased influence over company investment decisions (Svensson 1986, 297). Essentially, the wage earner fund proposal, as originally developed by the Swedish LO, called for the development of investment funds fed by company profits but controlled collectively by organized labor (Campbell et al. 1990, 499).

Detailed in the 1975 Meidner Report, the wage earner fund scheme was criticized by leaders of the nonsocialist parties as too "socialistic." This opposition, coupled with the defeat of the Social Democrats in the 1976 general election, all but assured that no immediate policy action would be taken. However, this lack of progress in developing a mutually acceptable policy did not bring about the death of the idea. Instead, after regaining majority status in 1982 the Social Democrats, in response to continued pressure from organized labor, proceeded (somewhat reluctantly) to implement a modified version of the proposal, in which the unions were not given total control over the funds to be established.

It is important to stress here that although a profit-sharing policy ultimately was adopted, it was not the product of consultation and compromise. Rather, it was adopted through the "superior power of one party, which was little restrained by its adversaries" (Campbell et al. 1990, 500). This is best reflected by the fact that, since its inception, employers have continued to oppose the plan, and many simply have chosen not to participate on the boards of directors of the established wage earner funds. Employers, in effect, have boycotted the funds, and as of yet no leading capitalists have accepted positions on the boards (Svensson 1986, 298).

The anticorporatist posture assumed by the SAF during the wage earner fund controversy has become even more pronounced in recent years. In 1991, for instance, the SAF removed its representatives from several key corporatist advisory bodies, including the joint boards for labor market policy and occupational health and safety. In response, the government was forced to develop new legislation that called for the effective elimination of the boards and the establishment of new advisory bodies to be composed of people appointed by the government on the basis of their expertise, rather than as representatives of specific interest groups (EIRR 1992, 9-11). 
While Sweden represents a fairly clear example of a state where practices of corporatist governance have declined over the past decade, the most widely discussed case of corporatist decline and instability continues to be that of Germany, where corporatistic processes of industrial relations and public policymaking have eroded in recent years (Dyson 1982; Streeck 1984; Jacobi 1986; Mueckenberger 1986; Fuchs and Koch 1989).

The German system of corporatist policymaking emerged during the growth years of the mid-1960s, when, with the enactment of the 1967 Law for Promoting Stability and Growth in the Economy, the German government officially recognized itself as an active participant in the direction of the national economy. The Law, in effect, mandated a role for the national government in economic management, not only in its endorsement of Keynesian demand-management techniques but in its call for the establishment of state-supervised tripartite policymaking committees. By the late 1960 s, corporatist arrangements had expanded to the point where decison making and advisory bodies composed of coalitions of organized business, trade union, and government representatives were in place to participate in the development, formation, and implementation of policies in such areas as wage and price controls, social security, and industrial development and reorganization. Of greatest importance in the transformation to corporatism, however, was the government's introduction of the Konzertierte Aktion program, which established a formal process of consultation among the Council of Economic Experts, the Ministry of Economics, the federal bank, employers' associations, and the German Federation of Trade Unions (Fuchs and Koch 1989, 4). Officially, the central objectives behind the government's promotion of concerted action were to prevent the expansion of inflationary pressures and to establish concertative institutional mechanisms through which coordinated growth strategies could be developed (Dyson 1982, 38).

As a result of these developments, Germany, for many analysts (e.g., Lehmbruch 1979), had become a rather well-established "neocorporatist" state by the late 1960s. But by the end of the decade these assumptions concerning German corporatist practice were brought into question as the process of concerted action began to break down. Later, as Fuchs and Koch suggest, the political climate reinforced the idea that Germany "was moving away from corporatism, as the neoliberal economic policies of Britain and the United States appeared as the emerging model of policy articulating in the 1980s" $(1989,5)$.

The collapse of concerted action during the 1970s perhaps represented the most profound example of corporatist decline in Germany, as organized capital's increasing unwillingness to develop centralized wage agreements with labor during this recessionary period signalled the emergence of a 
fairly significant strain in the "social partnership" that earlier had characterized labor-management relations and economic policymaking processes (Dyson 1982, 38). Thus, as in the cases of Sweden and the other Scandinavian democracies, industrial relations in Germany now tend to be sectoral in scope, with wage and benefit agreements being reached with employers by individual unions rather than through centralized negotiations at the national level.

The decline of corporatist concertation in Germany is evident as well in certain political and economic changes that transpired during the first several years of the current bourgeois government of Helmut Kohl. Influenced by arguments originally voiced by representatives of Germany's dominant employers' confederation (the BDI), Kohl became convinced that centralized corporatist policymaking practices, which typically produce comprehensive and uniform regulations of a wide range of labor-management relations, had become too burdensome for private capital in the sense that they tended to inhibit flexibility and innovation-qualities that are particularly important during economic downturns, when the need for change in investment strategies is most crucial (Streeck 1984, 293). For Kohl and the BDI leadership, then, a weakening of federally-based corporatist linkages, coupled with supply-side investment-inducing tax policies, effectively would generate managerial flexibility and risk-taking in the private sector. This attitude is reflected in the government's Annual Economic Report of January 1983, which stated that the economic upturn of the late 1970s "masked the growing weakness of the fabric of the economy," which became more visible following the second oil price shock of the early 1980s. A major reason for this development, the government argued, was "the substantial expansion of public sector economic intervention which increasingly prohibited the development of private initiative" (OECD 1985, 9). Thus, the government's economic programs for 1983 and 1984, as outlined in its Annual Economic Reports for those two years, stressed the need to scale back the size of the public sector in order to free resources for the private sector and to stimulate growth, to reduce public sector borrowing, to dismantle regulations that hinder flexibility in the labor market, and to transfer responsibility for certain activities from government institutions to the private sector (OECD 1985, 11).

This latter initiative has been reflected in the Kohl government's abandonment of national tripartite bargaining mechanisms as a means to formulate economic and social policy. Essentially, the government now relies upon irregular, informal bipartite meetings, primarily with industrialists, as a means of informing producer group representatives of state positions on matters of wage and industrial policies (Hancock 1989, 138). 
Consequently, the government has pursued strategies aimed at decentralizing and deregulating economic decision making processes. Included here are policies that have established a foundation for sectoral industrial policy development.

Under concerted action the responsibility for the formation of industrial policies was centered at the federal level, as representatives of organized business and labor, acting in concert with government officials, worked to develop extensive national industrial policy guidelines. However, since the mid-1980s, decentralized processes of industrial policy formation have been promoted. For example, through federal government financial support, local and regional "technology centers" have been established to promote innovation by supporting small and medium-sized firms. These centers have become a popular means of developing sector-based industrial policy, and their operations are governed by local (rather than federal) government agencies that may or may not seek the advice of local trade union leaders (Fuchs and Koch 1989, 8-9).

Such strategies for decentralizing Germany's economic decision making processes clearly reflect the BDI's current tendency to favor sectoral and market-based forms of economic policymaking and industrial relations over the traditional style of macrocorporatist governance prevalent during the 1960s and 1970s. And while the process of decorporatization in Germany no doubt has been hurried along by the presence of a generally market-oriented government, it is important to stress that in Germany (and elsewhere) the movement away from concertative forms of economic management appears to have been initiated by organized capital, which during the early 1980s simply became less willing to participate constructively in what always had been voluntaristic corporatist bargaining practices.

\section{Conclusion}

It may be suggested, then, that even the social democratic parties of western Europe, which historically have been most supportive of corporatism, would be unrealistic to continue to promote centralized concertative forms of policymaking. It is unlikely-given the realities of the postindustrial economic order and the attendant changed attitude of capital toward corporatism - that such a political economic environment would receive enough support from capitalists to facilitate the kind of private sector investment activity that is currently needed for long-term macroeconomic restoration. As Hancock notes:

Democratic corporatism, as opposed to "state" (or coercive) corporatism, presupposes voluntary compliance with authoritative policy decisions of organized interest groups. 


\title{
412 | Mark Gobeyn
}

\begin{abstract}
A key incentive for compliance lies in institutional and individual efficacy among group members with respect to policy decisions that affect their lives. This condition was met [in some countries] with respect to both organized labor and employer associations in the formative years of postwar political transformation $(1989,134)$.
\end{abstract}

In the postindustrial societies of today, however, it seems that this condition is not being met, as organized capital — economically the most vital participant in corporatist policymaking arrangements-no longer appears willing to adhere to principles of corporatist concertation.

It is the voluntary nature of corporatism that renders it most vulnerable to instability. Essentially, in the absence of state coercion, both of society's historically combative producer groups, capital and labor, must remain supportive of corporatist forms if they are to continue to function effectively. Additionally, for corporatist bargaining structures to remain intact, the state must continue to view corporatist concertation as a viable means of formulating government policy. In viewing the decline of corporatism in Europe, then, it would seem that its origins should be traced not so much to forces that have emerged outside of corporatist policymaking structures (as some students of postmaterialism maintain), as to the actions of certain actors operating within these structures whose interests no longer were best served by such arrangements.

It has been suggested here that capitalists' changed attitudes toward corporatism are the primary forces behind the decline of corporatist governance, and that these changed views can be traced in part to certain economic and technological features of the new postindustrial order that have acted to weaken the bargaining powers of organized labor. The central premise underlying this argument has been that the postwar corporatist forms in the western European democracies were developed during periods when the potential for labor militancy was significant, and that labor's integration into state policymaking and administrative structures represented a distinct tradeoff in which trade unions were accorded official policymaking privileges in exchange for their agreement to maintain moderate wage demands and a generally cooperative relationship with capital. Corporatism, in effect, represented a form of industrial relations and economic policymaking that was most suitable for (and was most likely to be supported by) capitalists during the heyday of industrial capitalism, when the power position of the working class vis-à-vis capital was at its zenith. In the current postindustrial era, however, capital has regained its traditional position of dominance in the economic market, a development that has rendered corporatist forms of governance increasingly obsolete. 


\section{NOTES}

${ }^{1}$ For Wilson, social movements that would have a significant impact on democratic politics "must do more than simply achieve a few specific objectives; they must make some lasting changes in attitudes, behavior, and/or policies" $(1990,74)$. As such, his assessment of the contention that the existence of corporatism encourages the formation and heightens the presence and social legitimacy of postmaterialist pressure groups focuses upon measures of such indicators as public attitudes toward these new groups, the propensity for societal members to join them, and the inclination of the general public to approve of the kinds of "unconventional" political tactics often employed by them. Citing recent survey data collected to measure these indicators, Wilson found that compared to the publics in noncorporatist societies (Ireland, France, Britain, Italy), citizens of some of the corporatist-oriented democracies (Denmark, the Netherlands, Belgium, Germany) are not significantly more inclined to support, join, or accept as legitimate the political tactics associated with the postmaterialist pressure groups. This evidence, according to Wilson, raises serious questions about the strength of any alleged relationship between the overall pattern of interest group politics and the incidence of new social movements $(1990,74-78)$.

${ }^{2}$ The outbreak of labor unrest in Sweden and elsewhere in western Europe during the early 1980s convinced a few observers that trade unions had become disenchanted with corporatiststructured policies and with corporatist practices in general (see Marks 1985, 55-58). This argument later was reinforced by labor's temporary withdrawal from corporatist practices in both Sweden and Germany. However, as the following analysis seems to indicate, this labor-centered interpretation of corporatist instability arguably underemphasizes the crucial role initially played by employers' associations in influencing the unions' actions. Additionally, it should be noted that trade unions in western Europe today remain largely supportive of centralized, concertative forms of economic management, and have called for restorations of nationally-based corporatist institutional arrangements (Svensson 1986, 298; Hancock 1989, 141).

\section{REFERENCES}

Beer, Samuel H. 1982. Britain Against Herself: The Political Contradictions of Collectivism. New York: W.W. Norton.

Bell, Daniel. 1973. The Coming of Postindustrial Society. New York: Basic Books.

Bluestone, Barry and Bennett Harrison. 1982. The Deindustrialization of America. New York: Basic Books.

Cameron, David R. 1984. Social Democracy, Corporatism, Labour Quiescence and the Representation of Economic Interest in Advanced Capitalist Society. In John Goldthorpe, ed., Order and Conflict in Contemporary Capitalism. Oxford: Clarendon Press.

Campbell, Colin, Harvey Feigenbaum, Ronald Linden, and Helmut Norpoth. 1990. Politics and Government in Europe Today. New York: Harcourt Brace Jovanovich.

Dahrendorf, Ralf. 1989. Tertium Non Datur: A Comment on the Andrew Shonfield Lectures. Government and Opposition 24: 131-141.

Dyson, Kenneth. 1982. The Politics of the Economic Recession in West Germany. In Andrew Cox, ed., Politics, Policy, and the European Recession. New York: St. Martin's Press.

Edwards, Richard. 1986. Unions in Crisis and Beyond: Introduction. In Richard Edwards, Paolo Garonna, and Franz Todtling, eds. Unions in Crisis and Beyond. Dover, MA: Auburn House.

European Industrial Relations Review (EIRR). 1991. 215: 9. 1992. 218: 11.

Fuchs, Gerhard, and Andrew Koch. 1989. New Modes of Industrial Interest Intermediation in the West German State of Bavaria. Paper presented at the 1989 annual meeting of the European Studies Conference, Omaha, NE. 


\section{4 | Mark Gobeyn}

Gobeyn, Mark J. 1993. Corporatist Governance in Advanced Capitalism. Westport, CT: Greenwood Press.

Hancock, M. Donald. 1989. West Germany: The Politics of Democratic Corporatism. Chatham, NJ: Chatham House.

Harrison, Reginald. 1980. Pluralism and Corporatism: The Political Evolution of Modern Democracies. London: Allen and Unwin.

Hatch, Michael. 1991. Corporatism, Pluralism, and Postindustrial Politics. West European Politics 14: 73-97.

Heisler, Martin O. 1974. Politics in Europe: Structures and Processes in Some Postindustrial Democracies. New York: McKay.

Inglehart, Ronald E. 1971. The Silent Revolution: Intergenerational Change in Postindustrial Societies. American Political Science Review 65: 991-1017.

. 1977. The Silent Revolution. Princeton: Princeton University Press.

1979. Value Priorities and Socioeconomic Change. In Samuel Barnes and Max Kaase, eds., Political Action: Mass Participation in Five Western Democracies. Beverly Hills: Sage. 75: $880-900$

1981. Postmaterialism in an Age of Uncertainty. American Political Science Review

International Labour Office (ILO). 1975, 1986, 1990. Yearbook of Labour Statistics. Geneva: ILO.

Jacobi, Otto. 1986. Trade Unions, Industrial Relations, and Structural Economic Ruptures. In Otto Jacobi, Bob Jessop, Hans Kastendiek, and Marino Regini, eds., Economic Crisis, Trade Unions, and the State. London: Croom Helm.

Kitschelt, Herbert. 1986. Political Opportunity Structures and Political Protest: Anti-Nuclear Movements in Four Democracies. British Journal of Political Science 16: 58-95.

. 1990. New Social Movements and the Decline of Party Organization. In Russell J. Dalton and Manfred Kuechler, eds., Challenging the Political Order. New York: Oxford University Press.

Korpi, Walter. 1983. The Democratic Class Struggle. London: Routledge.

Lange, Peter, and Michael Wallerstein. 1992. The End of Corporatism? Paper presented at the 1992 annual meeting of the American Political Science Association, Chicago, IL.

Lasch, Christopher. 1972. Toward a Theory of Postindustrial Society. In M. Donald Hancock and Gideon Sjoberg, eds., Politics in the Post-Welfare State. New York: Columbia University Press.

Lehmbruch, Gerhard. 1979. Liberalism, Corporatism, and Party Government. In Philippe C. Schmitter and Gerhard Lehmbruch, eds., Trends Toward Corporatist Intermediation. Beverly Hills: Sage.

1985. Neocorporatism in Western Europe: A Reassessment of the Concept in CrossNational Perspective. Paper presented at the 1985 annual meeting of the International Political Science Association, Paris.

Marks, Gary W. 1985. State-Economy Linkages in Advanced Industrial Societies. In Norman J. Vig and Steven E. Schier, eds., Political Economy in Western Democracies. New York: Holmes and Meier.

Mueckenberger, Ulrich. 1986. Labour Law and Industrial Relations. In Otto Jacobi, Bob Jessop, Hans Kastendiek, and Marino Regini, eds., Economic Crisis, Trade Unions, and the State. London: Croom Helm.

OECD. 1985. Economic Surveys 1984/1985 (Germany). Paris: OECD.

1982. Economic Surveys 1981/1982 (Sweden). Paris: OECD.

Offe, Claus. 1987. Challenging the Boundaries of Institutional Politics: Social Movements Since the Sixties. In Charles Maier, ed., Changing Boundaries of the Political. Cambridge: Cambridge University Press.

Panitch, Leo. 1977. The Development of Corporatism in Liberal Societies. Comparative Political Studies 10: 61-90.

1980. Recent Theorizations of Corporatism: Reflections on a Growth Industry. British Journal of Sociology 31: 159-187. 
1981. Trade Unions and the Capitalist State. New Left Review 125:21-43.

1986. The Tripartite Experience. In Keith Banting, ed., The State and Economic Interests. Toronto: University of Toronto Press.

Pierce, John C., Nicholas P. Lovrich, Taketsugu Tsurutani, and Takematsu Abe. 1989. Public Knowledge and Environmental Politics in Japan and the United States. Boulder, CO: Westview Press.

Schmitter, Philippe C. 1974. Still the Century of Corporatism? Review of Politics 36: 85-131. 54-73.

. 1989. Corporatism is Dead! Long Live Corporatism! Government and Opposition 24

Streeck, Wolfgang. 1984. Neo-Corporatist Industrial Relations and the Economic Crisis in West Germany. In John Goldthorpe, ed., Order and Conflict in Contemporary Capitalism. London: Clarendon Press.

and Philippe C. Schmitter. 1991. From National Corporatism to Transnational Pluralism: Organizing Interests in the Single European Market. Politics and Society 19: 133-163.

Svensson, Lennert. 1986. Class Struggle in a Welfare State in Crisis. In Richard Edwards, Paolo Garonna, and Franz Todtling, eds., Unions in Crisis and Beyond. Dover, MA: Auburn House.

Tsurutani, Taketsugu. 1977. Political Change in Japan: Response to Postindustrial Challenge. New York: McKay.

Wanniski, Jude. 1979. The Way the World Works. New York: Basic Books.

Wilensky, Harold, and Lowell Turner. 1987. Democratic Corporatism and Policy Linkages. Berkeley: Institute of International Studies.

Wilson, Frank L. 1990. Neocorporatism and the Rise of New Social Movements. In Russell J. Dalton and Manfred Kuechler, eds., Challenging the Political Order. Oxford: Oxford University Press.

Wilson, Graham K. 1985. Business and Politics: A Comparative Introduction. New York: Macmillan.

Wood, David M. 1991. Power and Policy in Western European Democracies. New York: Macmillan. 
